\title{
Resonance of Existentialism on Pandemic literature: An Introspection of Pandemic Literature of the Past
}

\author{
Nencepreet Kaur \\ Research Scholar, Department of English, UILAH,Chandigarh University, Punjab, \\ ramanperry@gmail.com, https://orcid.org/oooo-ooo3-1589-9154
}

\begin{abstract}
Literature has always been impacted by the abject state of thought of humans existing in a particular time and era. A sense of meaning, or forging an explanation evinced within literature during the cataclysmic contemporary crisis of the pandemic, definitely resonates within the existentialistic paradigms. Not addressing the effects this humanitarian crisis has had on humans in literature is akin to being in a bubble of time and being immune to the devastation all around. The pandemic which is arguably one of the most horrific disasters of modern times has nearly irreversibly affected the outlook, imagination and thinking of humans. It will definitely have an irrefutable impact on the literary discourse of modern times. The interactions during a crisis of such proportions, the various texts, practices, the socio-economic and political repercussions have an indelible impact on the way the literature of that time is doled out as literature effectively represents the society and its sentiments in general. The essence of the present times is survival, with death gaping at all within close quarters and this is the root of an existential way of living which reflects in literature as well. This can be ascertained by introspecting pandemic literature of the past and the purpose of this paper is to analyze the resonance of existentialism in pandemic literature.
\end{abstract}

Keywords: Contemporary Crisis, Pandemic Literature, Existentialism.

\section{Introduction}

Literature not only has an indubitable and profound impact on people and society, but it is also in turn shaped by the very intricacies of life, resonance of human nature, its joys, sorrows, epiphanies and experiences. Literature lays bare the realities which are concatenated with the lives of all the living consciousnesses in the world. It wouldn't be wrong to say that humans have described their reflections from within the recesses of their mental states in varied situations and have also resonated the very conditions of life within such situations, in different forms of literary out pours. Pandemics reverberate life altering and irremediable changes in terms of the lives of the humans undergoing a crucial and extensive upheaval. People face changing realities, distorted realizations, cardinal shifts in paradigms of realities during a cataclysmic tribulation such as a pandemic. Upon cognitive rumination of the literature representing pandemics in the past we observe the profound similarity in the distraught situation. Jones S.(2020) believes that the well written literary works are suppliments to philosophical texts and the urgency of how one should live is experienced in an accute manner in stressful times like pandemics. She further believes that eventhough both literature and philosophy pursue the existential question of how one should live in such times, yet the novels written in these times are more successful at answering the existential questions. There are astute insights gained into the thought process and the perceptive

(C) AesthetixMS 2020. This Open Access article is published under a Creative Commons Attribution Non-Commercial 4.0 International License (http://creativecommons.org/licenses/by-nc/4.0/), which permits non-commercial re-use, distribution, and reproduction in any medium, provided the original work is properly cited. For citation use the DOI. For commercial re-use, please contact editor@rupkatha.com. 
realities of individuals existing within such apocalyptic manifestations of the pandemic. Uncertainties become the only reality within a pandemic and how existentialist thought prevails through within literature can be examined with a detailed introspection. The existential delirium is captured in various forms of literature, where the very existence becomes the source of pain arousing from the depravity of hope and an enquiry into the unending trauma caused by the invisible force of nature eating through the interwoven texture of humanity.

\section{How Pandemics permeate into literature resonating existentialism}

In order to attain self definition within a crisis of such proportions such as a pandemic, one tackles the troubles posed in the flux of anxiety perpetuating from the apocalyptic situation within existential paradigms. Malpas(2012) in his research work examines the existentialism in literature as a manifestation in those literary works that figure within existential crisis while refering to Albert Camus and Beckett. He examines in his study how existentialism emerges in literary albeit philosophical terms. Choudhary S.(2020) opines that despite occuring at different points of human history, the range of responses have been captured within existential paradigms at various levels and bear a similarity regardless of the time when such crisis occur or are captured.Upon contemplative introspection of literature during the Spanish Flu of 1918, one cannot help but observe the literary impact of one of the deadliest pandemics of the past century while veering into the illumination of how this shaped the works of literature of that time. One observes that in such literature, there is a constant threat of being faced with death which consequentially has the outcome of an absurd behavior. Ingram(2016) while elaborating on this absurdity says that the constant threat of mortality and a sense of confusion during the pandemic leads to an increase in 'absurdity' and a resultant 'panic stricken' behavior. It is this absurdity which trickles into and permeates in literary representations which characterise the existential state of people during the tumultuous chaos of a pandemic.Describing how the effects of pandemic seep into literature with respect to T.S Eliot's works, which resonate within the realms of existentialism, Outka (2020) observes that both T.S. Eliot and his wife caught the flu during Spanish flu pandemic and Eliot felt weighed down by what he described as the "domestic influenza" of both his health and life concerning his home and had an impending sense of worry that his mind had been affected by his illness. She describes this existential delirium in his work and says:

"The Waste Land - a poem about so many things and one that channels the larger zeitgeist of his moment-turns this uncertainty into a climate, with its fogs, its corpse-haunted domestic landscape, its pervasive sense of living death, and its delirious language" (Outka, 2020).

TS Eliot describes not only the external chaos but also the spiritual depravity attributing to the devastation and the existential catastrophe as evinced by the pandemic. Existential enquiry into life in perilous situations, which are rooted in the pandemic, find manifestation in many of his literary works. Eliot's poetry characterizes the hopeless, existential finitude, the inherent disorder in a world disillusioned by the ramifications of the prolonged effect of the pandemic and a World War. Eliot's Wasteland brings to fore the existential preoccupations marked by a characteristic fear of nothingness, the absurdity in the loneliness, an ongoing anxiety and a perpetual indifference. Ackroyd (1984) believed that T. S Eliot was aware of the void in human affairs during the world amidst conditions which were worsened with the war and the pandemic. While talking about the disorder and futility in Eliots's work he says: 
"the disorder, the meaninglessness, and futility which he found in his own experience; it was inexplicable intellectually.... and could only be understood or endured by means of larger faith"( Ackroyd, 1984, p.160).

The existential crisis is brought forth with a ubiquitous absurdity and an existential predicament when he reflects about the state of men who are:

Shape without form, shade without colour,

Paralysed force, gesture without motion(Eliot, 1958, p.1).

In his book The Pandemic Perhaps: Dramatic Events in a Public Culture of Danger (California, 2015) Cardiff believes in the perpetuation of an essentially existential culture of danger during pandemics and says:

"The feeling of fear associated with the exposure to existential threat, is at the heart of modern social contract" (2015, p.189).

The pandemic produces an atmosphere which is so dense and hard to untangle, so much so that the senses are permanently infused with it. Such sensorial reception of the cataclysm finds an infusion in literature. Bruneau, J.(1948) in his paper describing existentialism in the context of American novel, says that existentialists are responsible for a synthesis between the objective and the subjective as well as the absolute and the relative while novels bring about the primordial life gushing forth with its temporal verity. In her book Viral Modernism: the Influenza Pandemic and Interwar Literature (Newyork, 2019) Outka opines:

"These realms of experience- the sensory, the atmosphere, and the affective are often precisely the realms left out of written histories but infused into memories, poems and novels" (21019, p.6).

Another important manifestation of the realities infused by the pandemic is Katherine Anne Porter's Pale Horse, Pale Rider(New York, 1939) which is an important record of the outbreak of Spanish Flu, with autobiographical influences directly stemming from the pandemic of inequitable proportions and comparable to the contemporary situation that is faced by humanity today. Davis (2011 a) believes, while fictionalizing the pandemic, Porter created an everlasting and enduring memory of the situation and effectively connected her personal experience with the experience of millions of other victims. Karolina,S.(2019) believes that some features of an author resonate with existentialism eventhough the author might or might not be considered as an existentialist. Porter's work meanders through the existential realms while it soaks in the experiences of human devastation at both micro and macro levels. Porter's story delves into the vivid manifestation of the disease where the able bodied young are eventually marked by death. Schnell T. (2010) opines in her paper that existential indifference is essentially characterised by a low meaningfulness disassociated with crisis of any meaning.The very life imagined by the young couple Miranda and Adam is enmeshed in the concatenation of the phantasmagoric existence with the virus. There is no better manifestation of existential delirium as evinced in the condition of Miranda who gets infected by her beloved Adam who loses his life to the flu while at war. Miranda questions her existential plight thus:

The body is a curious monster, no place to live in, how could anyone feel at home there? Is it possible I can ever accustom myself to this place? (Porter, 1937, p.257).

Davis(2011 b) observes that in Porter's story, Miranda tries to control her memory by using her relationship with Adam as a shield against the war and the virus, thus intentionally substituting 
one set of experiences for another. This is quintessentially existential as surviving and existing coexist here. Miranda's plight finds definition within the existential realms even more as her will to live diminishes to only remain and exist with brevity of hope and nihilistic deprivation of any optimistic outcomes of life.

Porter's central character Miranda dreams of an invisible bow in recurrent nightmares where she finds her beloved dying again and again with her futile attempts at different ways of intervention. This is representative of a struggle to stay alive and to find a reason to continue the life being led despite the dread, without being robbed of its very existence. Kauffman, W. (1959) opines that according to the existentialist Heidegger, death is central to the existential thought and feels that existentialism essentially brings forth writers as well as phillosophers who consider the extreme experiences as the starting point of philosophy. In his book Heidegger and Criticism, Retrieving the Cultural Politics of Destruction.(Minneapolis, 1993) Spanos appropriates the Heideggerian philosophy that repetition resonates of existentialism and reminds one that on absence of possession of recollections or of any repetition, one's life resolves into an empty noise or a void.

Another author reverberating the raucous turbulence of the Spanish Flu is William Maxwell. He was a child during the pandemic who lost his pregnant mother to the flu. This had a tumultuous impact on him and resonated in various of his works but most profoundly in They Came like Swallows (New York, 1937) where he revisits this tumultuous period of time. Girard, R.(1955) believes that the writer is subjected to an existential psychoanalysis where nothing is accidental or incidental. Lehan, R. (1959) believes that the writers displaying existentialism in their writing are concerned with deciphering a meaning of their identity within the chaos of the world within a crisis. He says:

".... all are concerned with the meaning of identity in the modern world, the nature of good and evil, the possibility of fulfillment in the contemporary society, the source of values in a world without God, and the possibility and meaning of action in an ethical vaccum"(Lehan, 1959, p.1)

Maxwell's Swallows examines through third person limited perspective, the multi foliate aspects in terms of the experience of the ordeal of a Mid Western family during the flu. It is constantly surmounted by an uncertain guilt embroiled in the precarity of the situation examining the 'have-beens', 'what- ifs' and 'if-nots'. This is evident in the physical manifestation of the emotional and mental states throughout. Each trivial and innocent incident is a dreaded reminder of the contagion and is frought with anxiety of a possible transmission. Elizabeth, who is the mother, is ridden with anxiety as a repercussion of reading a newspaper article about influenza, when she complains facetiously of 'fever, pains, and depression'( 1937, p.24). This feeling is further echoed by her son Bunny, who responds after observing her discomfort in a similar manner. Even though Elizabeth doesn't contract the flu until much later in a crowded train, there is a hanging atmosphere of foreboding due to a trivial and innocent act of motherly love on her part like entering her infected son's room. It is the prominence of such despair and anxious uncertainties within the impending scare of the disease and prospective morbidity associated with it, that makes the pandemic literature resonate within existential realities and connects the past with the contemporary context as well.

John O' Hara, like Maxwell, was also a child when the Spanish flu outbreak occurred. His Work The Doctor's Son (New York, 1935) offers a renewed perspective on the Pandemic through the eyes of the protagonist Jimmy. Slochower, H (1948)believes that existentialism brings out the 
essence of the being while one exists within the life he leads and how one encounters with the world. He says:

"In this process of loosening, the mythical hero experiences alienation, fear and guilt. Yet he continues on his journey away from ' home', accepting the responsibility of his free action or his crime" ( Slochower, 1948, p.42).

While providing a panoramic view of the crisis in 1918, O'Hara's work focuses on the crisis management and targets the spotlight on the front liners, doctors and the inadequacies while managing the crisis. Udokang, E.J. (2016) opines that according to Sartre's existentialism, one sources out the implications of holding a position within the world not as a mere beast living for itself alone in the time of a crisis, albeit in a community with a multitude of other subjects. The existential delirium of the doctor within the community that he is envisaged to, is apparent from the account of the narrator Jimmy who is the Doctor's assistant. His plight to survive, carry on doing his job amidst the exhaustion and the reality of a sojourn with death is what presents this piece of pandemic literature in existential light. The following lines bear testimony to the doctor's existential struggle and his attempts to survive and exist amidst the delirious chaos as they exhibit his constant struggle to catch some sleep within the perplexity of the pandemic:

At first he would get it by going to his office, locking the rear office door, and stretching out on the floor or on the operating table. He would put a revolver on the floor beside him or in the tray that was bracketed to the operating table. He had to have the revolver, because here and there among the people who would come to his office, there would be a wild man or woman, threatening him, shouting that they would not leave until he left with them, and that if their baby died they would come back and kill him. ( 1935, p.3)

One can notice the absolute struggle to survive and to simply 'be' in the pandemic literature is presented in conceivable existential realities. This pursuit of 'being' and sustaining life amidst the oscillation within the disorder and the chaos finds ample depiction in pandemic literature which is indubitably reflective of existential thought. This resonates with Kierkegaard's concept of existence when he says:

"To be a person is to exist in the mode, not of being, but of becoming and what a person becomes is his own responsibility, the product of his will" (Kierkegaard, as cited in Gardiner, 1988, p.106).

There is an impending anxiety fuelled by the reality of death looming large in Pandemic literature. Neimeyer and Brunt (1995) refer to this as 'death anxiety' and while they opine that this has been a topic which has been researched extensively, they believe that 'death anxiety' might be defined as the innate force which is the driving motivational influence which tends to impact upon varied aspects of behavior and interaction. Such behaviors find permeation in the pandemic literature and are reflective of the catastrophic crisis.

Albert Camus was able to depict this existential absurdity in his The Plague (London, 1973) as the disease ravages the town of Oran in French Algeria, there is an element of abstraction with a realistic portrayal of life's existential struggles.Vulliamy (2015) talks about the cohabitation of humanity with death in Camus' La Peste, translated The Plague and says that this work of Camus describes vividly, a cohabitation and a simultaneous confrontation of death in an epic scale. He further observes that Camus brings out the need for humans to carry on existing in this world while facing adversity: 
"Camus offers us a way of abandoning our pointless quest for "oneness" with ourselves, but carrying on nevertheless, fighting: For some ill-defined moral justice, even though we have ceased to be able to define it" (Vulliamy, 2015).

Literature of Pandemic has always existed as there have been occurrences of mass contagion which induced experiences exuding horror, the rawness of pain in human existence evincing hopelessness and despair. One of the early mentions of such literature is Giovani Boccacio's "The Decameron" which constituted rendering of bawdy stories indulging in erotic pleasures while seven women and three men were quarantined in a Tuscan Villa in Florence. Riva, Benedetti and Cesana (2014) opine that later medieval writings like the Decameron emphasized human behavior and that the fear of contagion was responsible for an increase in vices which lead to a physical and moral death. Such vices were a palliative measure to exist and cope with the dismal reality of disease and mortality. Riva et al (2014) observe that Greek literary texts like Homer's Illiad and Sophocles' Oedipus the King also exhibit such a causal relationship between plague and morality. Pandemics importune definite eruption of various reactions which might be psycho social in nature and may be absurd. These reactions are a direct consequence of the pandemic and reflect the absurdity of the plague resonating within humanity trying to struggle existentially. Such reactions find permeation and an expressive outpour in literature of all times within the premises of calamities like Pandemics.

\section{Interpretive ruminations upon pandemic literature}

The Pandemics are life altering and humans face a shift within existential paradigms before, after and during the pandemic. The existential delirium is multifaceted, emanating from the threat of the invisible and seemingly invincible spirochete threatening the very existence of humanity. This finds ramifications in the entire cultural context where literature connects the past and the present and shapes a discourse which celebrates the triumph of human resilience. Pandemics manifest themselves in literature as a reckoning force capable of influencing lives and altering the dimensions of the presumed 'normal'. Literature is evinced in the existential landscape with an expressive empathy rather than a vicarious destructive account of the precarious nature of the human situation during a cataclysm such as a pandemic which mirrors the existential strife heightened during such time.

\section{References}

Ackroyd, P. (1984). T.S. Eliot A Life. New York: Simons and Schuster.

Bruneau, J. (1948). Existentialism and the American Novel. Yale French Studies, (1), 66-72. doi:10.2307/2928860

Cardiff, C. (2015). The Pandemic Perhaps: Dramatic Events in a Public Culture of Danger. Oakland, California: University of California Press.

Choudhary, S.(2020) Making Sense of the Chaos: Analysing the Covid Situation Through a Re-Reading of Albert Camus' The Plague and Defoe's A Journal of the Plague Year. Writers Editors Critics. 10(1), p11-17. 
Davis, D. A. (2011). The Forgotten Apocalypse: Katherine Anne Porter's "Pale Horse, Pale Rider," Traumatic Memory, and the Influenza Pandemic of 1918. The Southern Literary Journal, 43(2), 55-74. Retrieved August 12, 2020, from www.jstor.org/stable/23208856

Eliot T.S. (1958). The Complete Poems and Plays. Harcourt, New York: Harcourt, Brace and Company

Girard, R. (1955). Existentialism and Criticism. Yale French Studies, (16), 45-52. doi:10.2307/2929147

Jones, S. (2020). Literature: A Useful Tool for the Philosophical Counselor During a Pandemic. American Philosophical Practice : Journal of the American Philosophical Practitioners Association. 15(2/3), p2534-2545.

Ingram, A. (2016). Pandemic Anxiety and Global Health Security. In Smith, S. J. \& Plaine, R. (Ed.). Fear : Critical Geo Politics and Everyday life. New York: Routledge.

Karolina, S. (2019) Existentialism in Literature.6th SWS International Scientific Conference on Arts and Humanities. 481-488 DOI: 10.5593/SWS.ISCAH.2019.1/327.061

Kaufmann, W. (1959). Existentialism and Death. Chicago Review, 13(2), 75-93. doi:10.2307/25293517

Lehan, R. (1959). Existentialism in Recent American Fiction: the Demonic Quest. Texas Studies in Literature and Language, 1(2), 181-202. Retrieved October 18, 2020, from http://www.jstor.org/stable/40753540

Malpas, J(2012). Existentialism As Literature.The Cambridge Companion to Existentialism. Scrowell (ed) Cambridge: Cambridge University Press, pp 291-321.

Maxwell, W. (1937) They Came Like Swallows. New York: Harper \& Brothers.

Neimeyer, R.A., Brunt, V.D.(1995). Death Anarchy Dying: Facing the Facts(3.). Washington, DC: Taylor and Francis.

O'Hara, J. (1935) The Doctor's Son and Other Stories. New York: Harcourt, Brace and Company.

Outka, E. (2019). Viral Modernism: the Influenza Pandemic and Interwar Literature. New York: Columbia University Press.

Outka, E. (2020, April 04). How Pandemics Seep into Literature. the Paris Review. Retrieved from https://www.theparisreview.org/blog/2020/04/o8/how-pandemics-seep-into-literature/

Porter, K. A. (1939) Pale Horse, Pale Rider: Three Short Novels. New York: Harcourt, Brace and Company.

Riva, M. A., Benedetti, M., and Cesana, G.(2014). Pandemic Fear and Literature: Observations from Jack London's The Scarlet Plague. Emerging Infectious Diseases, 20 (10). 1753-1757. DOI 10.3201/eid2010.130278

Schnell, T.(2010). Existential Indifference: Another Quality of Meaning in Life. Journal of Humanistic Psychology. 50(3). 351-373. Doi: 101177/0022167809360259

Slochower, H. (1948). The Function of Myth in Existentialism. Yale French Studies, (1), 42-52. doi:10.2307/2928857

Spanos, W. V. (1993). Heidegger and Criticism, Retrieving the Cultural Politics of Destruction. Minneapolis: Minnesota Press.

Udokang, E. J.(2016). Implications of Sartre's Humanistic Existentialism. Journal of Comparative Literature and Aesthetics. 39(1/2). 83-96.

Vulliamy, E. (2015, January 05). Albert Camus's The Plague: a story of our, and all, times. The Guardian, Retrieved from https://www.theguardian.com/books/booksblog/2015/jan/o5/albert-camus-theplague-fascist-death-ed-vulliamy 